\title{
DYNAMIC FINITE ELEMENT ANALYSIS OF ROCKFILL DAMS*
}

${ }^{1}$ Water Eng. Dept., Faculty of Engineering, Zagazig University, Egypt.

${ }^{2}$ Structural Eng. Dept., Faculty of Engineering, Zagazig University, Egypt.

\begin{abstract}
:
A number of embankment dams have failed or suffered major deformations during earthquakes. Numerical modeling methods can provide a powerful tool to predict the response of dams to earthquake loading. In the present work, the seismic performance of rockfill dams is numerically studied using the software ADINA (Automatic Dynamic Incremental Nonlinear Analysis) based on finite element method. The study is carried out to investigate the analysis procedures and safety evaluation of rockfill dams, and to improve its stability under earthquake loading. The study also investigates the generation and dissipation of pore water pressure generated within the dam clay core, the effect of earthquake horizontal acceleration component, and upstream water level on the stability of rockfill dams. Results indicated that large deformations took place within the clay core of the rockfill dam that consequently caused large crest settlements accompanied by relatively high generation of pore water pressure within that core. Moreover, the crest vertical displacements which can be used as an index of dam stability were relatively large enough in some cases to be more than freeboard that leads to overtopping.
\end{abstract}

KEY WORDS: Dynamic Analysis; Rockfill Dam; Finite Element; Earthquake; Clay Core.

\section{DYNAMIQUE ANALYSE PAR ÉLÉMENTS FINIS DES BARRAGES EN ENRO- CHEMENT}

\section{RÉSUMÉ:}

Un certain nombre de barrages en remblai ont échoué ou ont subi des déformations importantes lors de séismes. Méthodes de modélisation numérique peut constituer un outil puissant pour prédire la ré-ponse des barrages à charge sismique. Dans le présent travail, la performance sismique des barrages en enrochement est numériquement étudiée à l'aide du logiciel ADINA (Automatic Dynamic Incrémental Analyse Non Linéaire) basée sur la méthode des éléments finis. L'étude est menée pour étudier les méthodes d'analyse et d'évaluation de la sécurité des barrages en enrochements et d'améliorer sa stabilité sous charge tremblement de terre. L'étude examine également la production et la dissipation de la pression interstitielle générée dans le noyau d'argile barrage, l'effet de la composante d'accélération sismique horizontale, et le niveau d'eau en amont de la stabilité des barrages en enrochements. Les résultats ont indiqué que des déformations importantes ont eu lieu au sein du noyau d'argile du barrage en enrochement qui a donc causé de grandes colonies de crête accompagnés de génération relativement élevé de la pression interstitielle au sein de ce noyau. En outre, les déplacements verticaux de crête qui peuvent être utilisés comme indice de stabilité du barrage étaient relativement assez grande dans certains cas à plus de franc-bord qui mène à débordement.

MOTS CLES: Analyse Dynamique; Barrage En Enrochement; Eléments Finis; Tremblement De Terre; Noyau D'argile.

* Received: 2/12/2012, Accepted: 23/12/2012, Ref. No. 130, (Original Paper)

** Contact author (eng_heldeeb@yahoo.com, +2 0 1226644747) 


\section{1- INTRODUCTION}

In the evaluation of dynamic seismic response of earth and rockfill dams, generally, external excitations such as seismic and wind loading, etc., demonstrate uncertainty and have a strong influence on the dam response. However, the uncertainties of material parameters may also likely affect the material response.

Therefore, the more reasonable consideration of the variability in material parameters as well as the uncertainties of earthquake induced ground motion in dynamic response analysis of rockfill dams should be accounted for. The seismic behavior of earth and rockfill dams under strong ground shaking is rather unpredictable as each large dam amounts to a prototype located at a unique site. Therefore, generalization of results from one site to another is hardly satisfactory. A reasonable expectation is that each strong earthquake that causes damage to dams will identify new features of the seismic behavior of the dam. Prediction of these new reactions may have been overlooked or considered to be of lesser importance. Distinctions are possible among the uncertainties in seismicity (e.g. location, time and magnitude of seismic event) and the uncertainties in characteristics of ground motion (e.g. acceleration time history) at a dam site, [9, 12 and 13].

In addition, in order to predict the nonlinear response of earth and rockfill dams under random ground motion, a time history analysis is essential. This analysis requires the generation of artificial ground acceleration time histories to widen the study range covering higher earthquake magnitudes, $[10,15]$.

Finite Element Method (FEM) is one of the most powerful numerical techniques available today for the analysis of complex structural and mechanical systems.

The behavior of soil under static load can be predicted and accurately described, this is not the case under dynamic random loading like earthquakes. This is mainly because soil static loading can be performed experimentally and the soil behavior under that load can be easily observed, [16].

In the present work, the seismic performance of rockfill dams is studied numerically using
ADINA software based on Finite Element Method. The study is carried out to investigate the procedures for analysis and safety evaluation of rockfill dams, and to improve its stability under earthquake loading. The main objectives of the current paper include:

1. Studying the effect of earthquake horizontal acceleration component on the seismic performance for rockfill dams,

2. Studying the effect of relative height of upstream water height $\left(\mathrm{H}_{\mathrm{w}} / \mathrm{H}\right)$ on the dam deformations during earthquake, and

3. Studying the effect of generation and dissipation of pore water pressure within the dam clay core due to earthquake shaking, as shown in Fig. (1).

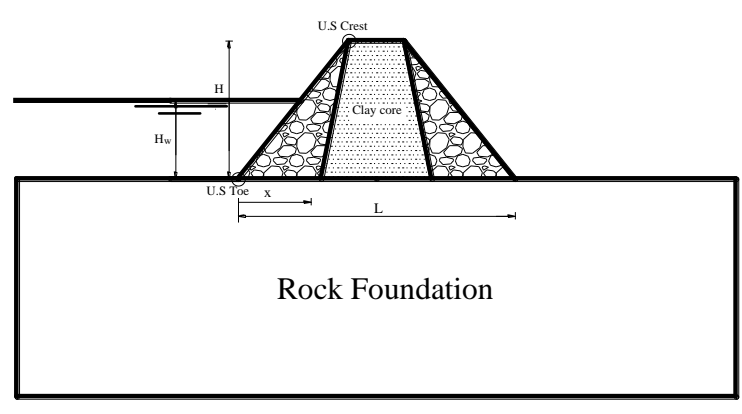

Fig. 1: Problem Definition

\section{2- NUMERICAL MODELS}

The stability of rockfill dam models is analyzed under two types of loading, static and dynamic (earthquake type).

Analysis Stage I (Static Loading Pattern): In this loading stage the soil is allowed to consolidate under its own weight and the weight of dam with water in the reservoir.

Analysis Stage II (Dynamic Loading Pattern): This is the main analysis event or the dynamic analysis stage, in which the model and the soil are subjected to earthquake type loading. In which case, the pore water pressures and soil stresses will be studied. In addition, lateral deformations and stresses will be also discovered in the foundation soils and the dam. 
The dam and surrounding soil domain is modeled as plane strain. The finite element model, as presented in ADINA software is shown in Fig. (2). these parameters are best estimated in Table (1), [14].

Table 1: Properties for Foundation and Dam Soils

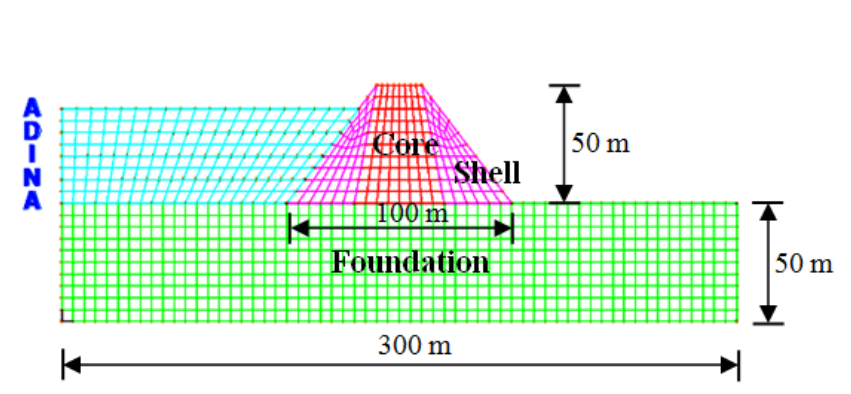

Fig. 2: Finite Element Meshing

The finite element mesh of the in-hand problem is shown in Fig. (2). The soil is modeled using 4-node plane strain element with 2 displacement degrees of freedom at each node. In addition an extra fluid pressure node is added at each corner node to account for the effect of presence of water within the saturated soil media, and add the ability to model the generation and dissipation of pore water pressure at such locations. The overall dimensions extend to a great length in the perpendicular direction, allowing the soil to be modeled as plane strain. It is assumed that just one soil layer of uniform properties exist throughout the mesh, under the dam.

The Mohr-Coulomb soil model is used in the analysis for its efficiency and simplicity in characterizing the non-linear soil behavior under static and dynamic conditions. The model is a two parameter model, mainly characterized by the well known soil shear strength parameters (c and $\phi)$, in addition to the soil modulus (E), and the Poisson's ratio (v). Soil angle of dilation $(\psi)$ can also be fed to the program considering the case of a non-associated flow rule, [16].

\section{3- MATERIAL PARAMETERS}

Rockfill dam foundation systems are nonhomogeneous structures constructed from rockfill and clay core materials. Since estimates of the material parameters of such dam types arise from limited datasets, and vary from place to place within resulting deposits,

\begin{tabular}{|l|c|c|c|c|}
\hline \multicolumn{1}{|c|}{ Parameter } & Units & Core & Shell & Foundation \\
\hline Dry density $(\rho)$ & $\left(\mathrm{kN} / \mathrm{m}^{3}\right)$ & 18.0 & 23.0 & 26.0 \\
\hline Young's modulus $(\mathrm{E})$ & $(\mathrm{MPa})$ & 20 & 10000 & 20000 \\
\hline Poisson's ratio $(\mathrm{v})$ & -- & 0.45 & 0.35 & 0.35 \\
\hline Cohesion $(\mathrm{C})$ & $(\mathrm{MPa})$ & 0.15 & 1.0 & 10.0 \\
\hline Friction angle $(\phi)$ & Degree & 15 & 20 & 10 \\
\hline
\end{tabular}

\section{3-1 MOHR-COULOMB MATERIAL MODEL}

The Mohr-Coulomb model is based on a non-associated flow rule, a perfectly-plastic Mohr-Coulomb yield behavior, with tension cut-off. The Mohr-Coulomb model can be used with the 2-D solid and 3-D solid elements with small displacement/small strain, large displacement/small strain and large displacement/large strain formulations. When used with the small displacement formulation, a materially-nonlinear-only formulation is employed and when used with the large displacement/small strain formulation, a TL formulation is employed and when used with the large displacement/large strain formulation, a ULH formulation is employed. The MohrCoulomb yield function is given by, [4]:

$$
\begin{aligned}
& { }^{t} f_{M C}={ }^{\mathrm{t}} I_{1} \sin \phi+\frac{1}{2}\left(3(1-\sin \phi) \sin ^{\mathrm{t}} \theta+\sqrt{3}(3+\right. \\
& \left.\sin \phi) \cos ^{\mathrm{t}} \theta\right) \sqrt{{ }^{t} J_{2}}-3 C
\end{aligned}
$$

and the corresponding potential function is written as:

${ }^{t} g_{M C}=$
${ }^{t} I_{1} \sin \psi+\frac{1}{2}\left(\begin{array}{l}3(1-\sin \psi) \sin { }^{t} \theta+ \\ \sqrt{3}(3+\sin \psi) \cos { }^{t} \theta\end{array}\right) \sqrt{{ }^{t} J_{2}}-3 C$

Where:

$$
{ }^{t} \theta=\frac{1}{3} \cos ^{-1}\left(\frac{3 \sqrt{3}}{2} \frac{{ }^{t}}{t_{3}^{3 / 2}}\right)
$$


$\phi=$ Friction angle (material constant), $\mathrm{C}=\mathrm{Co}-$ hesion (material constant), ${ }^{t} \mathrm{I}_{1}=$ First stress invariant at time $t,{ }^{t} J_{2}=$ Second deviatoric stress invariant at time $\mathrm{t}, \psi=$ Dilation angle (material constant), ${ }^{t} J_{3}=$ Third deviatoric stress invariant at time t, as shown in Figs. (3) and (4).

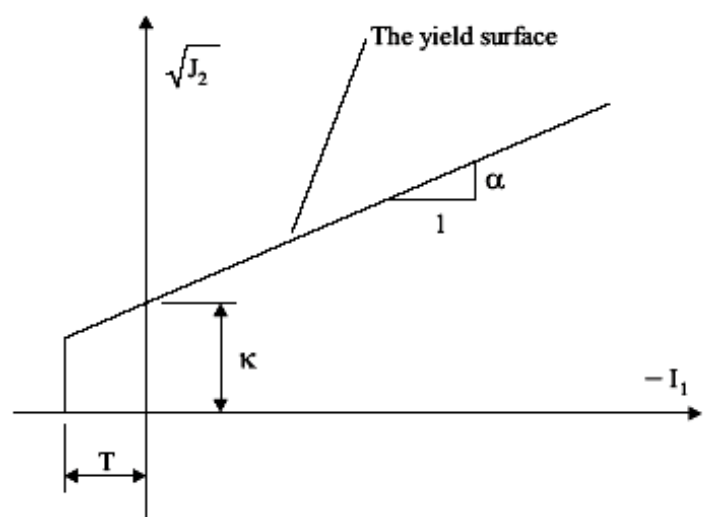

Fig. 3: Mohr-Coulomb Model in $I_{1} v s \sqrt{J_{2}}$ Space

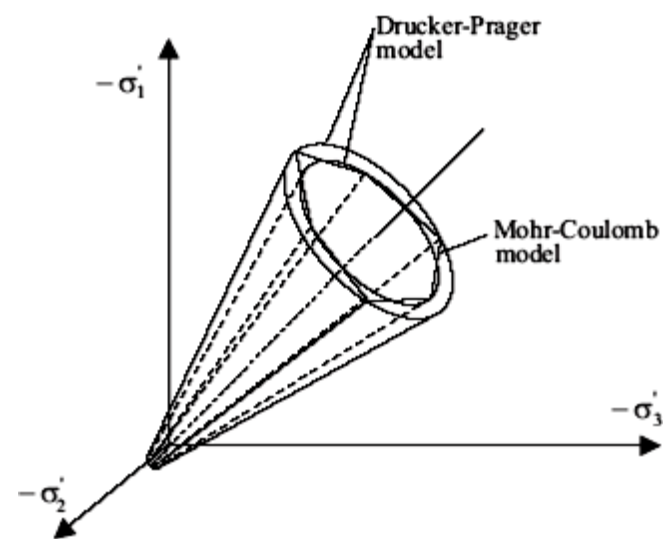

Fig. 4: Yield Surfaces of the Mohr-Coulomb and Drucker-Prager models

\section{3-2 BOUNDARY CONDITIONS}

There are two classes of boundary conditions: essential boundary conditions, such as prescribed displacement (and rotation) boundary conditions, and natural boundary conditions, such as applied force and moment boundary conditions. All displacement and force boundary conditions can be referred to the global Cartesian system or to predefined skew systems. In such case, the skew systems are right-handed orthogonal systems that have arbitrary orientations with respect to the global Cartesian coordinate system.

The axes of a skew system are defined using the input of direction cosines, Euler angles, or axes. Skew systems can be assigned to any nodal point or through the associated geometry in AUI (Adina User Interface) module of the software ADINA. Once a node is associated with a skew system, the velocities and loads are referred to that skew system.

In ADINA software pressure loading, distributed loading and mass proportional loading calculates first the corresponding consistent nodal load vectors (consistent in the sense that the principle of virtual work is used) and then assembles these load vectors into the externally applied load vector.

\section{4- EARTHQUAKE RECORD}

The Northridge earthquake occurred at 4:30 a.m. local time on January 17, 1994. Northridge is located about $30 \mathrm{~km}$ northwest of Los Angeles. This earthquake had a 6.9 moment magnitude. The hypocentral depth was $19 \mathrm{~km}$. The duration was about $10 \mathrm{se}-$ conds to 20 seconds. The earthquake occurred along a "blind" thrust fault, close to the San Andreas fault, [6].

The displacement and acceleration-time histories of the Northridge earthquake are shown in Figs. (5a) and (5b), [3].

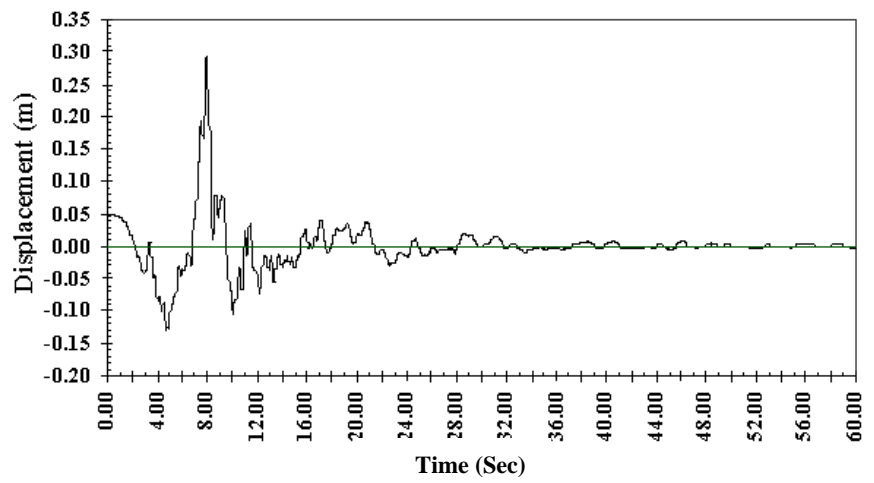

Fig. 5a: Displacement time-history of the Northridge earthquake 


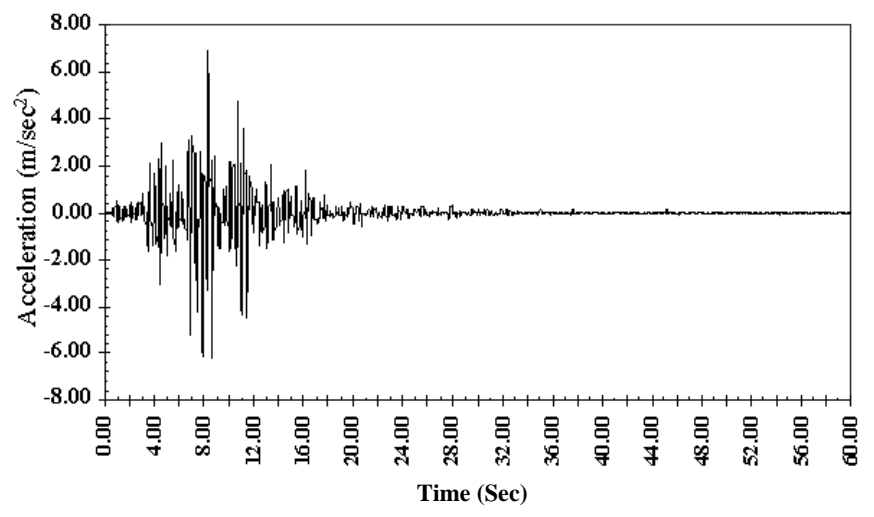

Fig. 5b: Acceleration time-history of the Northridge earthquake

\section{5- PARAMETERS IDENTIFICATION}

The effect of relative height of upstream water surface, $\left(\mathrm{H}_{\mathrm{w}} / \mathrm{H}\right)$ and the earthquake intensity on the stability of rockfill dams with clay core during earthquake along with the pore water pressure generated in rockfill dams and its clay core due to earthquake shaking are studied in this analysis. The study was performed under variation of relative height of upstream water surface $\left(\mathrm{H}_{\mathrm{w}} / \mathrm{H}\right), 0.2,0.4,0.6$ and 0.8 , and variation of earthquake horizontal acceleration component, static condition, $0.1 \mathrm{~g}$ to $0.7 \mathrm{~g}$ with an increment equals $0.1 \mathrm{~g}$.

\section{6- ANALYSIS OF RESULTS}

The relative height of water in the reservoir and earthquake horizontal acceleration component variation effects were studied for rockfill dams. Deformations that took place at the dam crest along with stresses within the dam clay core and its foundations are also presented in the analysis.

\section{6-1 Dam Crest Settlement}

The presence of the clay core within the dam shell sides resulted in lateral and vertical displacements within the dam crest. The deformation characteristics of the clay are much higher than that of the base rock and broken rock shell. This is caused the noticeable vertical (settlement) and lateral deformations in the dam crest.

Fig. (6) presents the settlement time history relative to dam height at the upstream crest for different earthquake horizontal acceleration components which varies from $0.1 \mathrm{~g}$ to $0.7 \mathrm{~g}$ with an increment of $0.1 \mathrm{~g}$, during the total duration of strong shaking lasting for 20 seconds.

A static relative settlement of $0.2 \%$ is noticed during and after the construction period. However, when the earthquake shaking started a sudden relative settlement of $1 \%$ took place. The total relative settlement including the static ones varies from 1, 1.06, 1.2, 1.22, 1.48, 1.5 and $1.8 \%$ of dam height as the earthquake horizontal acceleration component varies from $0.1 \mathrm{~g}$ to $0.7 \mathrm{~g}$ with an increment equals $0.1 \mathrm{~g}$.

The settlements for all the studied earthquake magnitudes match from the beginning of the static solution and even the through the first 7.92 second during the dynamic analysis, which represents the peak horizontal component during the earthquake. Large changes began to be noticeable after this peak and continue till the end of the earthquake. The maximum settlement increases as the earthquake horizontal acceleration component increases, especially for earthquake acceleration of $0.50 \mathrm{~g}$ or more.

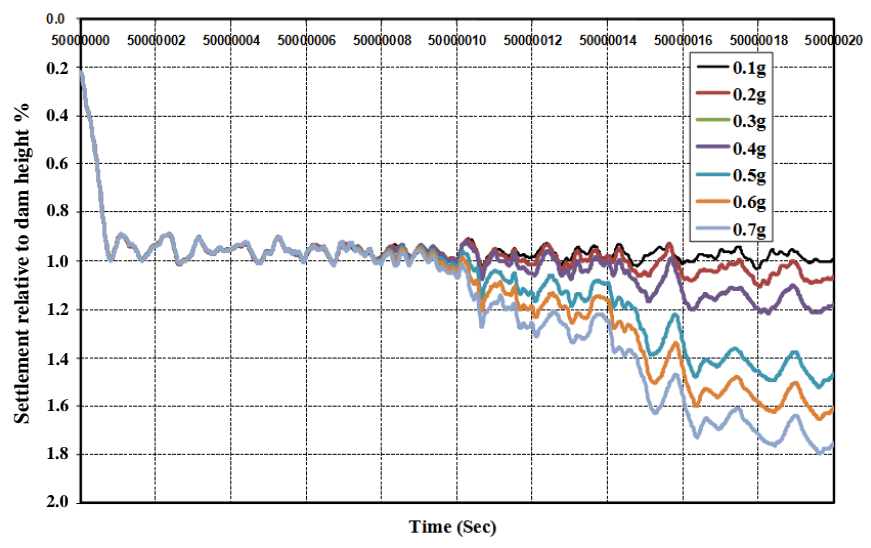

Fig. 6: Settlement time history, $\mathrm{H}_{\mathrm{w}} / \mathrm{H}=\mathbf{0 . 8}$, for different earthquake intensities, U.S Crest

\section{6-2 Stress Distribution}

Fig. (7) represents the maximum stress distribution along the dam base for different earthquake horizontal acceleration components which varies from $0.1 \mathrm{~g}$ to $0.7 \mathrm{~g}$ with an increment of $0.1 \mathrm{~g}$. The figure shows that a relative increase in the stresses within the dam clay core preceded and followed by a noticeable decrease of stresses within the dam upstream and downstream shells. The figure also shows 
that increasing the earthquake magnitude does not case a noticeable variation in the generated stresses except at the starting point of the clay core in which relatively large stress variation took place. This stress variation may be attributed to the large drop in the permeability from the highly permeable shell and the impermeable dam clay core.

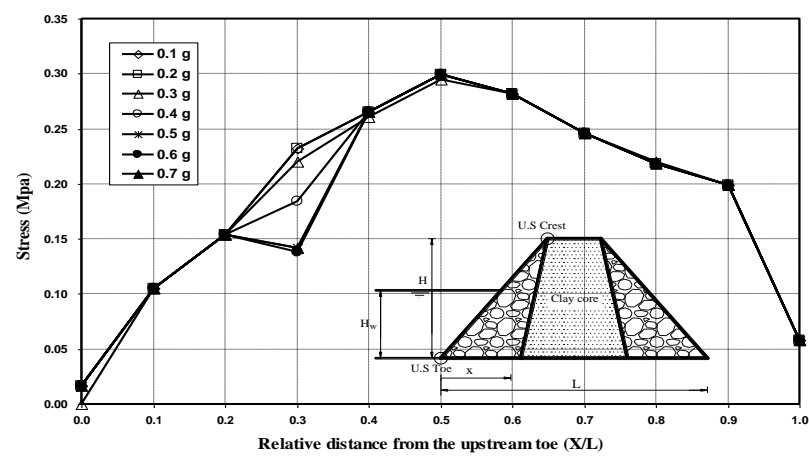

Fig. 7: Maximum stress distribution along the dam base for $\mathrm{H}_{\mathrm{w}} / \mathrm{H}=0.2$

Fig. (8) shows that the maximum stress is $0.27 \mathrm{MPa}$ at the middle of clay core and it ranges from 0.04 to $0.27 \mathrm{MPa}$. It is noticed that the stresses at the beginning of the clay core at $\mathrm{x} / \mathrm{L}=0.3$ varies for different earthquake horizontal acceleration components. The maximum stress decreases by $10 \%$ from the first case thus may be due to the increase in the generated pore water pressure.

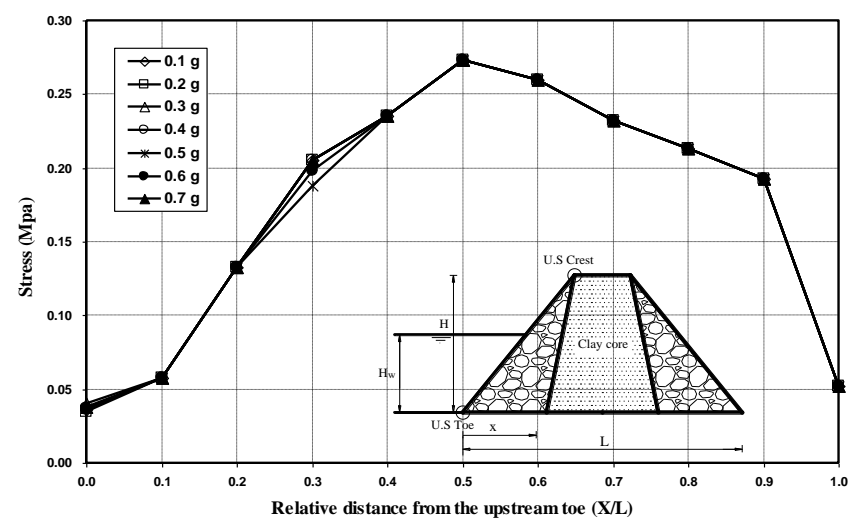

Fig. 8: Maximum stress distribution along the dam base for $\mathrm{H}_{\mathrm{w}} / \mathrm{H}=\mathbf{0 . 4}$

It is noticed, from Fig. (9) that the maximum stress is $0.25 \mathrm{MPa}$ and occurs at $\mathrm{x} / \mathrm{L}=0.5$. The maximum stress increases from $\mathrm{x} / \mathrm{L}=0$ to $\mathrm{x} / \mathrm{L}=0.5$ then it decreases from $\mathrm{x} / \mathrm{L}=0.5$ to $\mathrm{x} / \mathrm{L}=1.0$, and it ranges from 0.02 to $0.25 \mathrm{MPa}$. It is noticed that, the stress at the beginning of clay core and varies for different earthquake horizontal acceleration components. The maximum stress decreases by $16.7 \%$ from the first case. On the other hand, Fig. (10) shows that the maximum stress is $0.22 \mathrm{MPa}$. The maximum stress increases from $\mathrm{x} / \mathrm{L}=0$ to $\mathrm{x} / \mathrm{L}=0.5$ then it decreases from $\mathrm{x} / \mathrm{L}=0.5$ to $\mathrm{x} / \mathrm{L}=1.0$, and it ranges from 0.03 to $0.22 \mathrm{MPa}$.

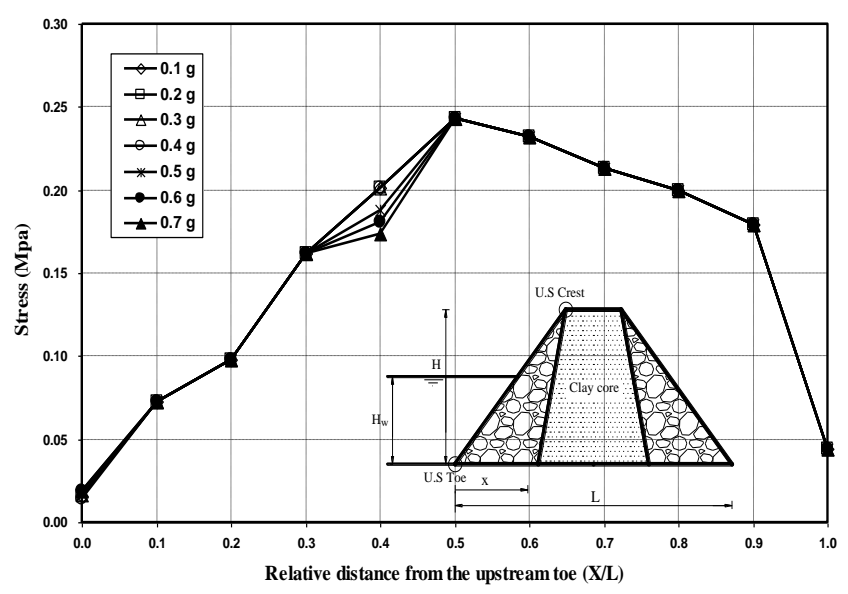

Fig. 9: Maximum stress distribution along the dam base for $\mathrm{H}_{\mathrm{w}} / \mathrm{H}=0.6$

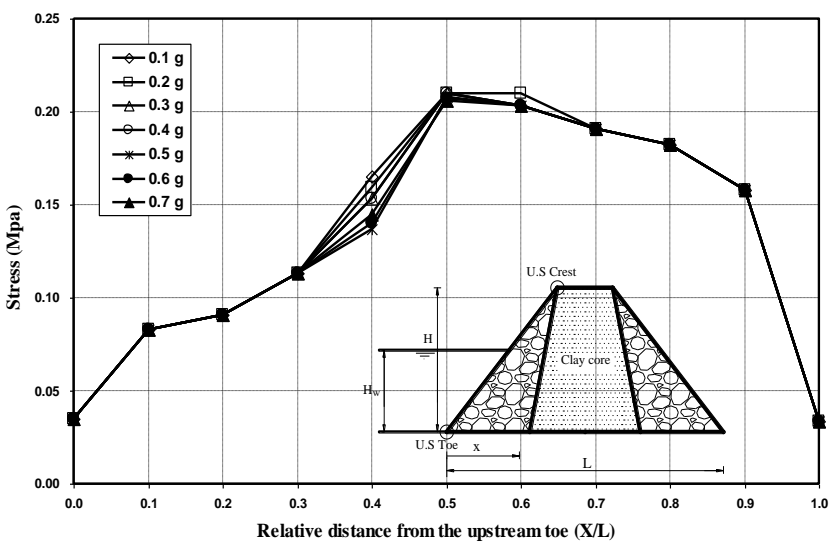

Fig. 10: Maximum stress distribution along the dam base for $\mathrm{H}_{w} / \mathrm{H}=0.8$

\section{6-3 Horizontal Displacement within the Whole Domain}

Figs. from (11) to (14) present the horizontal displacement in the dam and the clay core as well as the foundation for different earthquake horizontal acceleration component. The study was performed under variation of relative upstream water height $\left(\mathrm{H}_{\mathrm{w}} / \mathrm{H}\right), 0.2,0.4,0.6$ and 0.8 . 


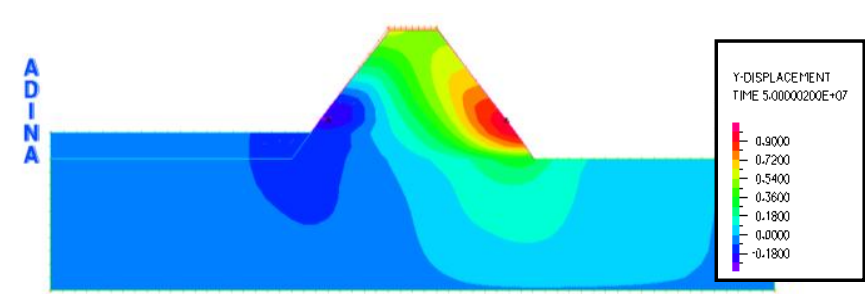

Fig. 11: Effect of HL. displacement, at earthquake HL. Acceleration $0.4 \mathrm{~g}$, for $\mathrm{H}_{\mathrm{w}} / \mathrm{H}=0.2$

Results indicate that the maximum horizontal displacement occurs within the lower portion of the downstream shell.

Increasing the relative upstream water height $\left(\mathrm{H}_{\mathrm{w}} / \mathrm{H}\right)$ have a noticeable effect on the lateral displacement distribution within the dam this may be due to the lateral water pressure generated as presented in Fig. (15) and Figs. (11) through (14).

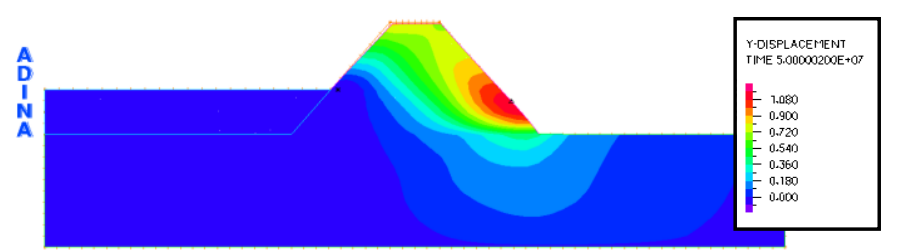

Fig. 12: Effect of HL. displacement, at earthquake HL. Acceleration $0.4 \mathrm{~g}$, for $\mathrm{H}_{\mathrm{w}} / \mathrm{H}=\mathbf{0 . 4}$

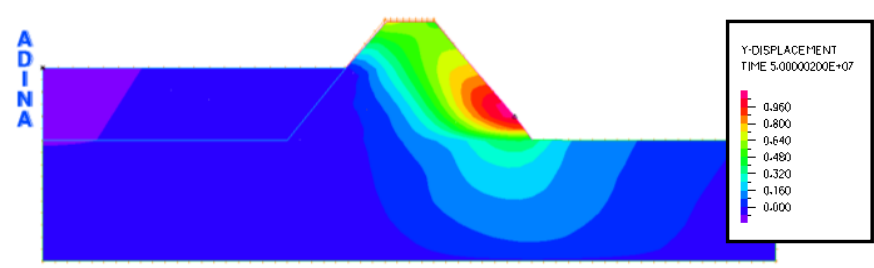

Fig. 13: Effect of HL. displacement, at earthquake HL. Acceleration $0.4 \mathrm{~g}$, for $\mathrm{H}_{\mathrm{w}} / \mathrm{H}=\mathbf{0 . 6}$

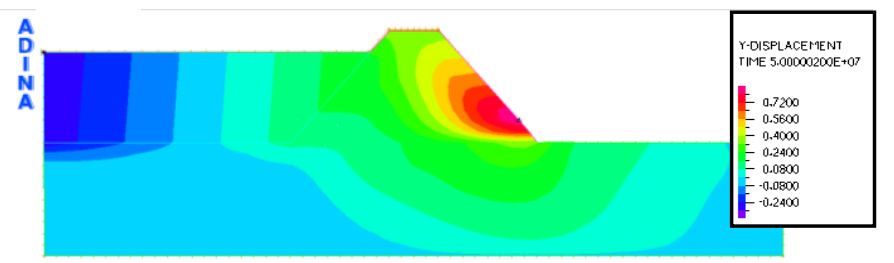

Fig. 14: Effect of HL. displacement, at earthquake HL. Acceleration $0.4 \mathrm{~g}$, for $\mathrm{H}_{\mathrm{w}} / \mathrm{H}=0.8$

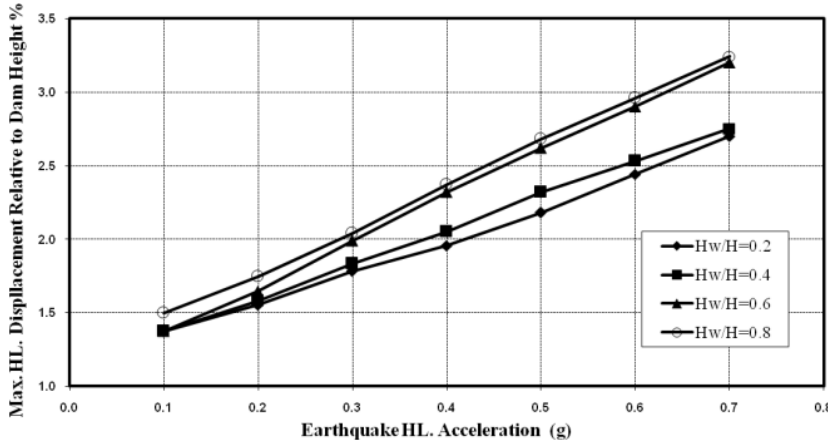

Fig. 15: Max. HL. displacement relative to dam height \%, with variation of $\mathrm{H}_{\mathrm{w}} / \mathrm{H}$ ratio

\section{6-4 Pore Water Pressure Generated}

Fig. (16) shows variation of the maximum pore water pressure along the distance from the upstream toe relative to the dam base length, $\mathrm{x} / \mathrm{L}$, for different earthquake horizontal acceleration components varying from $0.1 \mathrm{~g}$ to $0.7 \mathrm{~g}$ with an increment equals $0.1 \mathrm{~g}$. It is noticed that, the change of earthquake horizontal acceleration component, has a significant effect on the pore water pressure distribution in clay core zone, with maximum value 0.56 MPa at the end of the clay core base. It is also found that the change of earthquake horizontal acceleration component, has a slight effect on the pore water pressure distribution within the upstream and downstream dam shells.

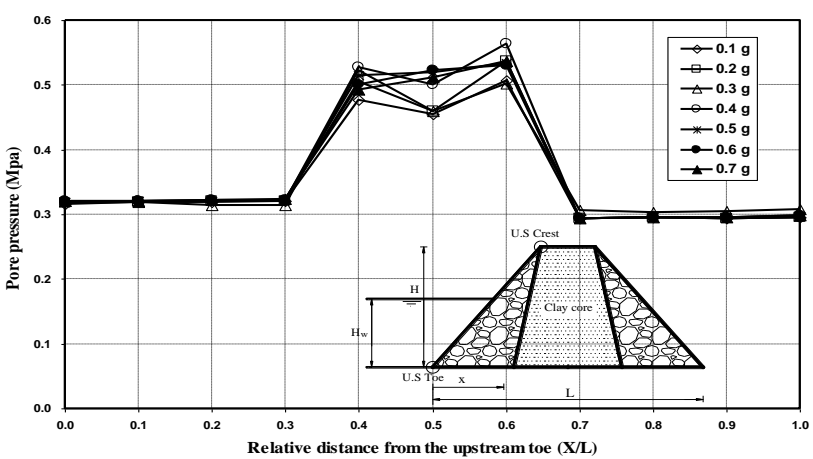

Fig. 16: Maximum pore pressure distribution along the dam base for $\mathrm{H}_{\mathrm{w}} / \mathrm{H}=\mathbf{0 . 2}$

Fig. (17) shows that the maximum value of pore water pressure is $0.6 \mathrm{MPa}$ at the end of clay core base with an increment equals $7.1 \%$ from the previous case $\mathrm{H}_{\mathrm{w}} / \mathrm{H}=0.2$. It is also found that the change of earthquake horizontal acceleration component has a very slight effect on the generated pore water pressure within the upstream and downstream dam shells due to their relatively higher permeability. 


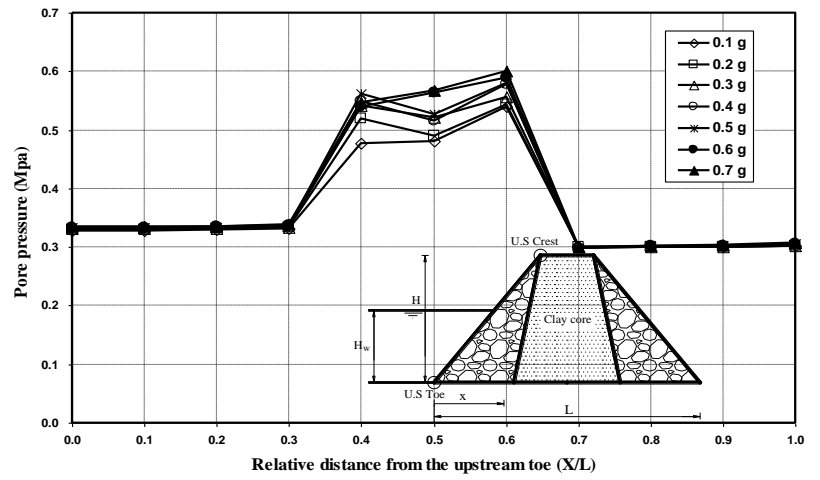

Fig. 17: Maximum pore pressure distribution along the dam base for $\mathrm{Hw} / \mathrm{H}=0.4$

The maximum values are equal to 0.33 and 0.3 $\mathrm{MPa}$ in the upstream and downstream shells respectively.

It is noticed from Fig. (18) that the maximum value of pore water pressure is $0.64 \mathrm{MPa}$ which is $14.3 \%$ higher than the case of $\mathrm{H}_{\mathrm{w}} / \mathrm{H}=0.2$. The pore water pressure distribution increases slightly in the upstream shell due to the rise in reservoir operation water elevation. The maximum values are 0.35 and 0.31 $\mathrm{MPa}$ in upstream and downstream shell respectively.

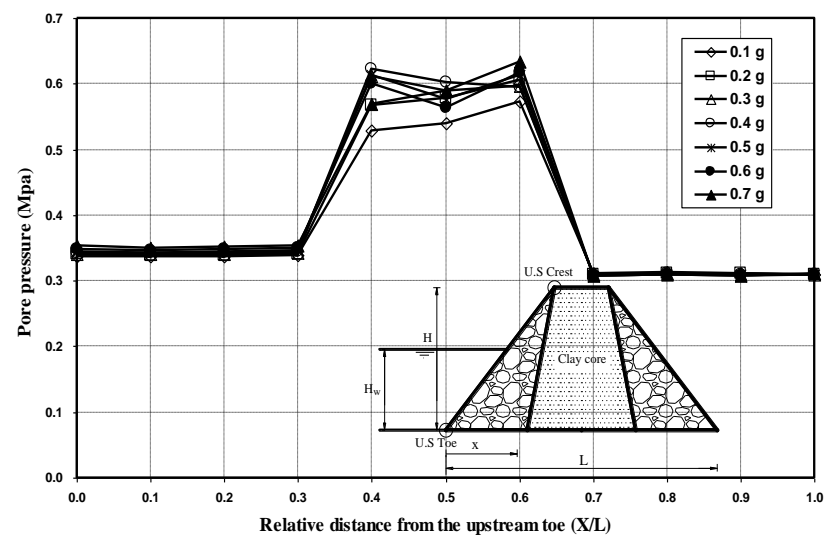

Fig. 18: Maximum pore pressure distribution along the dam base for $H_{w} / H=0.6$.

Fig. (19) shows that the maximum value of pore water pressure is $0.68 \mathrm{MPa}$ with an increment equals $21.4 \%$ with respect to the case of $\mathrm{H}_{\mathrm{w}} / \mathrm{H}=0.2$. The maximum values are 0.47 and $0.32 \mathrm{MPa}$ in upstream and downstream shells respectively. It is found that, the pore water pressure changes obviously in the upstream shell with variation of $\mathrm{H}_{\mathrm{w}} / \mathrm{H}$ ratio.

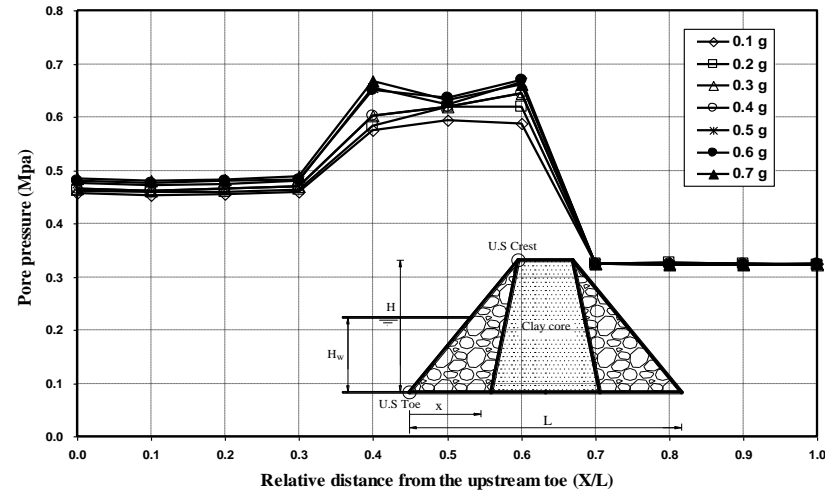

Fig. 19: Maximum pore pressure distribution along the dam base for $\mathrm{H}_{\mathrm{w}} / \mathrm{H}=\mathbf{0 . 8}$

\section{7- CONCLUSIONS}

From the previous analysis of the results, the following conclusions are obtained:

* In case of rockfill dam with clay core on rock foundation, most of the dam crest vertical and lateral displacements for both static and dynamic analyses are caused by the relatively low stiffness of the dam clay core. Thus, the stiffness of the clay core should be increased when possible to avoid such large vertical and lateral deformations.

* The maximum settlement due to consolidation in static analysis is $0.2 \%$ of dam height. The total settlement including the settlement due to consolidation increases to $1 \%$ of dam height for the earthquake horizontal acceleration component, $0.1 \mathrm{~g}$. It increases from $1.06 \%$ to $1.8 \%$ of dam height as the earthquake horizontal acceleration component varies from $0.2 \mathrm{~g}$ to $0.7 \mathrm{~g}$ with an increment equals $0.1 \mathrm{~g}$.

* Earthquakes, even with low magnitude, cause relatively large settlements in the dam crest. However, larger earthquake magnitudes showed relatively larger settlements when the earthquake peak acceleration is reached. Thus the recommended values of freeboard should be greater than $1.5 \%$ of dam height in zones of moderate earthquakes to avoid overtopping of the upstream water.

* The maximum lateral displacements within the rockfill dam took place at the lower portion of the downstream dam shell. This may be attributed to the higher pressure caused by the upstream water accompanied by the lateral 
displacements caused by the earthquake shaking. The relatively soft nature of the clay core along with the higher vertical stresses within such core may also attribute to that increase in the lateral displacements.

* The maximum stresses occur at the middle of the base for the rockfill dam with a relative distance from the upstream toe along the dam base of $x / L=0.5$. Highest stresses are mostly concentrated within the clay core of the dam. The maximum stress decreases with the increase of relative height of water in reservoir, $\mathrm{H}_{\mathrm{w}} / \mathrm{H}$. The decrement percentages are from $10 \%$ to $26.7 \%$ for increasing $\mathrm{H}_{\mathrm{w}} / \mathrm{H}$ ratio from 0.2 to 0.8 respectively.

* Increasing the earthquake horizontal acceleration component has a significant effect on pore water pressure distribution along the dam base and within the clay core. The low permeability of clay core blocks the water flow from the upstream into the downstream shells of the dam. However, the maximum pore water pressure increases with increasing the relative height of water in the reservoir, $\mathrm{H}_{\mathrm{w}} / \mathrm{H}$. The increment percentages in the maximum generated pore water pressure are from $7.1 \%$ to $21.4 \%$ for increasing $\mathrm{H}_{\mathrm{w}} / \mathrm{H}$ ratio from 0.2 to 0.8 respectively.

\section{REFERENCES}

1- Abdel-Ghaffar, A.M., Scott, R.F., and Craig, M.J., (1980), "Full scale experimental investigation of a modern earth dam", California institute of technology, Earthquake engineering research laboratory, A report on research conducted, Report No. 80-02.

2- Abouseeda, H., and Dakoulas, P., (1998), "Non-linear dynamic earth dam-foundation interaction using a BE-FE method", John Wiley \& Sons, Earthquake engineering and structural dynamics, Vol. 27, pp. 917-936.

3- Bardet, J.P., and Davis, C.A., (1996), "Performance of San Fernando dams during 1994 Northridge earthquake", Journal of Geotechnical Engineering, Vol. 122, No. 7, Paper no. 10555.

4- Bathe, K.J., (2011), "ADINA/Standard User's Manual, Version 8.7.3", Watertown, USA.
5- Bouaanani, N., and Lu, F.Y., (2009), "Assessment of potential-based fluid finite elements for seismic analysis of dam-reservoir systems", Elsevier, Computers and Structures, Vol. 87, pp. 206-224.

6- Field, E.H., Johnson, P.A., Beresnev, I.A., and Zeng, Y., (1997), "Nonlinear ground motion amplification by sediments during the 1994 Northridge earthquake", Journal of Nature, Vol. 390.

7- Getachew, F., (2002), "Comparison of Pseudo-Static and Dynamic response analysis of Sibilu dam", Unpublished M.Sc. Thesis, School of Graduate Studies, Addis Ababa University.

8- Gogoi, I., and Maity, D., (2010), "A novel procedure for determination of hydrodynamic pressure along upstream face of dams due to earthquakes", The $14^{\text {th }}$ World Conference on Earthquake Engineering, October 1217, Beijing, China.

9- Haciefendioglu, K., Bayraktar, A., and Basaga, H.B., (2009), "Estimation of stochastic nonlinear dynamic response of rock-fill dams with uncertain material parameters for non-stationary random seismic excitation", Springer, Nonlinear Dynamic, December, No. $10.1007 / \mathrm{s}$.

10- Karbasi, M.S., and Byrne, P.M., (2004), "Embankment dams and earthquakes", Hydropower and Dams, Issue two.

11- Khattab, A.F., (1991), "Design of Dams", Second Edition, Research Institute of Weed Control and Channel Maintenance, Water Research Center, Ministry of Public Works and Water Resources, Cairo, Egypt.

12- Kim, M.K., Lee, S.H., Choo, Y.W., and Kim, D.S., (2011), "Seismic behaviors of earth-core and concrete-faced rock-fill dams by dynamic centrifuge tests", Elsevier, Soil Dynamics and Earthquake Engineering, Vol. 31.

13- Marcuson, W.F., (2007), "Seismic design and analysis of embankment dams: The state of practice", The Donald M. Burmister Lecture, Department of civil engineering and engineering mechanics, Columbia University, October 9. 
DYNAMIC FINITE ELEMENT ANALYSIS OF ROCKFILL DAMS

Mowafy, Salem, Salem, El Deeb

14- Moayed, R.Z., and Ramzanpour, M.F., (2008), "Seismic behavior of zoned core embankment dam", EJGE, Vol. 13.

15- Ozkan, M.Y., (1998), "A review of considerations on seismic safety of embankments and earth and rock-fill dams", Elsevier, Soil Dynamics and Earthquake Engineering, Vol. 17, pp. 439-458.

16- Salem, T.N., (1997), "Analysis of Offshore Piles", Unpublished ph.D. Thesis, Department of Structural Design, Zagazig University, Zagazig, Egypt. 